\title{
Anti-inflammatory Effect of Flower Bud and Fruit of Sweet Persimmon, Diospyros kaki T.
}

\author{
Yeo Ok Park ${ }^{1,3, \text {, }}$, Jeong Ah Lee ${ }^{1, \$, *}$, Seong Moon Park ${ }^{1, *}$, Min Hee Ha ${ }^{1, *}$, \\ Woo Hong $\mathrm{Joo}^{2, * *}$ and Dong Wan Kim ${ }^{1, \dagger, * *}$ \\ ${ }^{I}$ Department of Biohealth Sciences, College of Natural Sciences, \\ Changwon National University, Changwon 51140, Korea \\ ${ }^{2}$ Department of Biology and Chemistry, College of Natural Sciences, \\ Changwon National University, Changwon 51140, Korea \\ ${ }^{3}$ Sweet Persimmon Research Institute, Jinyeong, Gimhae, Gyeongnam 50871, Korea
}

\begin{abstract}
Various beneficial effects of sweet persimmon (Diospyros kaki T.) including anti-oxidation, anti-bacteria and viruses, anti-allergy were widely reported previously. However, the anti-inflammatory effect and its molecular mechanisms are not clear. In this study, the anti-inflammatory effect of the extracts of flower bud and fruit of sweet persimmon was investigated in LPS-treated RAW264.7 cells. Both extracts of flower bud and fruit showed strong inhibitory effect on

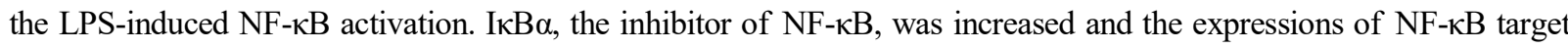
genes, COX-2 and iNOS, were suppressed by the treatment with the extracts of flower bud and fruit. The expressions of pro-inflammatory cytokines, IL-1 $\beta$, IL-6, TNF- $\alpha$ were also suppressed by the extracts. In addition, the LPS-induced wnt $\beta$-catenin pathway and its related gene expressions including cyclin D1, wnt $3 \mathrm{a}$, wnt $5 \mathrm{a}$ were suppressed by the extracts. The extracts also showed anti-oxidant activity and suppressive effect on the LPS-induced apoptosis of RAW264.7 cells. These results suggest that the flower bud and fruit of sweet persimmon display strong anti-inflammatory effect through inhibiting the pro-inflammatory signaling pathways in the cells.
\end{abstract}

Key Words: Sweet persimmon, Anti-inflammatory, NF-kB, Wnt/B-catenin, Anti-oxidant

\section{서 론}

단감(Sweet Persimmon)은 동양지역 특유의 과실로서 단 맛이 강한 알칼리성 식품으로 피부노화를 일으키는 활성 산소를 제거하고(Uchida et al., 1987), 팩틴이 풍부하여 중 성지방, 콜레스테롤 감소 효과를 나타내며 고혈압, 동맥 경화 예방 효과가 있는 것으로 알려져 있다(Choi et al.,
2006; Lee et al., 2006). 또한 단감은 다량의 섬유소를 함 유하여 장 수축 및 장액 분비 촉진 효과가 있으며(George and Redpath, 2008), 항균 및 항암 작용을 가지는 것으로 알려져 있다(Achiwa et al., 1997; Song et al., 2000). 특히 단감 의 탄닌 성분은 탁월한 소염 작용과 항염증 작용을 나타 내며, 실제 동물 실험에서 감 추출물은 알러지 염증의 개 선 효과를 보이는 것으로 보고되었다(Kotani et al., 2000). 그러나 아직 단감의 항염증 작용에 대한 분자생물학적 기

Received: June 4, 2020 / Revised: June 25, 2020 / Accepted: June 27, 2020

${ }^{*}$ Graduate student, ${ }^{* *}$ Professor.

${ }^{\S}$ These authors contributed equally to this research.

${ }^{\dagger}$ Corresponding author: Dong Wan Kim. Department of Biohealth Sciences, College of Natural Sciences, Changwon National University, Changwon 51140 , Korea.

Tel: +82-55-213-3482, Fax:+82-55-213-3480, e-mail: dwkim@changwon.ac.kr

(OThe Korean Society for Biomedical Laboratory Sciences. All rights reserved.

@ (This is an Open Access article distributed under the terms of the Creative Commons Attribution Non-Commercial License (http://creativecommons.org/licenses/by-nc/3.0/) which permits unrestricted non-commercial use, distribution, and reproduction in any medium, provided the original work is properly cited. 
전이 밝혀져 있지 않아 단감의 항염증 효과에 대해서는 논란의 여지가 남아있다. 한편, 체내 염증반응(inflammatory response)은 유해한 자극에 대한 생체반응으로 세 포의 손상을 억제하고 상처 부위의 파괴된 조직 및 괴사 된 세포를 제거하며 조직을 재생하기 위한 방어 작용에 속한다(Kuprash and Nedospasov, 2016). 하지만 만성적 염증 반응은 오히려 질병을 일으키는 원인이 되기도 하는데 류 머티즘 관절염, 만성 염증성 장 질환, 심뇌혈관 질환 등 다양한 형태로 나타난다(Sartor, 1997; Symmons, 2015). 특히 장기간의 반복된 염증의 발생과 치유는 혈관 생성을 촉 진하고 폐암, 방광암, 대장암, 췌장암, 흑색종 등의 염증 성 암을 일으키는 원인으로 알려져 있다(Ben-Neriah and Karin, 2011; Hanahan and Weinberg, 2011). 이러한 염증반응 의 시작은 체내 면역세포에 염증 유발 물질이 작용하였 을 때 Toll-like receptors (TLRs)의 활성화에 의한 NF- $\mathrm{kB}$ 의 활성화, MAPKs 및 wnt/ $\beta$-catenin 회로의 활성화, apoptosis 의 증가 등 많은 세포 내 signaling pathway의 변화에 의 해 일어나는 것으로 밝혀져있다(Tak and Firestein, 2001; Clevers and Nusse, 2012). 본 연구에서는 단감의 항염증 효 능에 대한 명확한 증거를 제시하여 항염증 기능성 식품 또는 항염증 의약품 원료로서 단감의 유용성을 높이기 위 해 체내 염증 유발의 핵심적인 역할을 하는 macrophage 세포(Li et al., 2018)에서 단감의 항염 작용에 대한 분자생 물학적 기전 연구를 수행하였다. 특히, 적뢰 및 적과시 폐 기되는 단감의 꽃봉오리와 어린 과실의 추출물을 이용하 여 항염 작용을 증명함으로써 단감의 활용성 증대에 도 움을 주고자 하였다.

\section{재료 및 방법}

\section{감 추출물 제조}

태추 단감의 꽃봉오리 추출물은 적뢰시 꽃받침을 포함 한 꽃봉오리를 잘라 사용하였고, 어린 과실 추출물은 적 과시 과실을 채집하여 사용하였다. 채집된 꽃봉오리와 과 실은 액체질소를 첨가하여 마쇄한 후 24시간 동안 동결 건조하였다. 동결 건조된 꽃봉오리와 과실은 $70 \%$ ethanol 에서 24시간 추출한 후 여과(Whatman No.1)하고 진공 감 압 회전 농축기로 농축하여 동결 건조하였다. 동결 건조 한 추출물은 dimethylsulfoxide (DMSO)에 녹인 후 실험에 사용하였다.

\section{세포배양 및 transfection}

RAW246.7 macrophage 세포를 Fetal bovine serum (FBS)이 $10 \%$ 함유된 Dulbecco's Modified Eagle Medium (DMEM) 을 사용하여 $37^{\circ} \mathrm{C}, 5 \% \mathrm{CO}_{2}$ 의 incubator에서 배양하였으며, FBS와 DMEM 배지는 Gibco BRL Co. (Grand Island, NY. USA) 제품을 사용하였다. 세포에 plasmid DNA를 도입하 기 위한 transfection은 FuGENE 6 (Promega, Madison, WI, USA)를 사용한 lipofection 방법으로 하였으며 sample 당 $10 \sim 20 \mu \mathrm{g}$ 의 DNA를 serum free DMEM과 FuGENE 6의 혼 합액에 섞고 실온에서 20 분간 반응시켜 lipid와 DNA의 복합체를 형성시킨 다음 recipient cell에 적하하고 배양하 였다. Recipient 세포는 70 80\%의 밀도로 배양된 것을 사 용하였다.

\section{MTT assay}

RAW264.7 세포를 $1 \times 10^{4}$ cells/well로 96-well plate에 분 주하여 24시간 배양 후 꽃봉오리 및 과실 추출물을 농도 별로 $\mathrm{DMSO}$ 에 희석하여 각 well에 투여하고 5 시간 배양 하였다. 추출물을 투여한 각 well에 MTT solution을 $0.5 \mathrm{mg}$ $/ \mathrm{mL}$ 첨가하여 4시간 동안 배양한 후 상등액을 제거하고 DMSO $200 \mu \mathrm{L}$ 에 녹여 $570 \mathrm{~nm}$ 에서 흡광도를 측정하였다. Cell viability (\%)는 추출물 미처리군의 흡광도에 대한 처 리군의 흡광도의 비율로 나타내었다.

\section{Luciferase assay}

Luciferase gene을 포함한 NF- $\kappa \mathrm{B}$ 의 reporter plasmid는 pNL3.2 NF-kB RE (Promega, code N1111)를 사용하였으며 이는 Luciferase promoter 부위에 5 개의 NF- $\mathrm{NB}$ 결합 부위를 가지고 있다. Luciferase activity의 측정은 Nano-Glo Substrate (Promega)를 Nano-Glo buffer (Promega)에 100배 희석하여 사용하였으며 cell lysate는 96-well plate에 $20 \mu \mathrm{L}$ 씩 분주하 여 사용하였다. Substrate는 luminometer program (Microwin assay reader 2000, Centro LB960, Berthold Technologies, Bad Wildbad, Germany)을 이용하여 노즐을 70\% Ethanol로 50회 wash하고 멸균 증류수로 50회 wash한 후 투여하였다. 효 소반응은 $20 \mu \mathrm{L}$ 씩 substrate가 분주되도록 하였으며 luciferase activity를 10 초 간격으로 측정하였다.

\section{Western blotting}

시료 단백질을 $10 \% \mathrm{SDS}$ polyacrylamide gel에서 전기영 동 한 후 $90 \mathrm{~V}$ 로 2시간 동안 nitrocellulose membrane (GE 
Table 1. Primer sequences for RT-PCR

\begin{tabular}{llc}
\hline \hline Gene & \multicolumn{1}{c}{ Primer Sequences $\left(5^{\prime} \rightarrow 3^{\prime}\right)$} & $\begin{array}{c}\text { Amplicon } \\
\text { length }\end{array}$ \\
\hline IL-1 $\beta$ & $\begin{array}{l}\text { F: GTGTGTGACGTTCCCATTAGA } \\
\text { R: TTAGAAACAGTCCAGCCCATAC }\end{array}$ & 491 \\
\hline IL-6 & $\begin{array}{l}\text { F: GATAAGCTGGAGTCACAGAAGG } \\
\text { R: GAAACCATCTGGCTAGGTAACA }\end{array}$ & \multirow{2}{*}{412} \\
\hline TNF $\alpha$ & $\begin{array}{l}\text { F: GAAAGTCAGCCTCCTCTCCG } \\
\text { R: CTTTCAGTCGGAGGAGAGGC }\end{array}$ & \multirow{2}{*}{194} \\
\hline Cyclin & $\begin{array}{l}\text { F: CATCTACACCGACAACTCCATC } \\
\text { D1 }\end{array}$ & \multirow{2}{*}{ R: TCTGGCATTTTGGAGAGGAAG } \\
\hline Wnt 3a & $\begin{array}{l}\text { F: TGTTGGGCCACAGTATTCCT } \\
\text { R: ATGAGCGTGTCACTGCAAAG }\end{array}$ & \multirow{2}{*}{302} \\
\hline Wnt 5a & $\begin{array}{l}\text { F: AATTCTGGCTCCACTTGTTG } \\
\text { R: CAATTACAACCTGGGCGAAG }\end{array}$ & \multirow{2}{*}{148} \\
\hline GAPDH & $\begin{array}{l}\text { F: GAAGGTGAAGGTCGGAGTCAA } \\
\text { R: GCTCCTGGAAGATGGTGATG }\end{array}$ & \multirow{2}{*}{179} \\
\hline
\end{tabular}

F: forward, R: reverse

Healthcare Life Science, Germany)에 electrotransfer한 뒤 5\% 탈지분유를 포함한 TBS-T (20 mM Tris-HCl (pH 7.6), 197 $\mathrm{mM} \mathrm{NaCl}, 0.1 \%$ Tween-20) 용액으로 1시간 동안 실온에 서 blocking 하였다. Membrane을 1차 항체와 실온에서 2 시간 반응시키고 TBS-T 용액으로 3회 세척한 후 peroxidase가 부착된 2차 항체로 1시간 동안 실온에서 반응시켰 다. 반응시킨 membrane을 TBS-T 용액으로 3 회 세척한 후 enhanced chemiluminescence (ECL, Amersham Corp. Arlington Heights, IL, USA)로 발광시킨 후 Amersham Imager 600 (GE Healthcare)을 이용하여 결과를 확인하였다. 항체는 anti$\mathrm{I} \kappa \mathrm{B} \alpha(\mathrm{C}-21)$, anti-p-IкB $\alpha$ (sc-8404), anti-actin (I-19), anti-iNOS (sc-651), anti-Bcl2 (sc-7382), anti-Bax (sc7480), anti-COX-2 (sc-1745) (Santa Cruz Bio Technology, CA, USA), anti- $\beta$-catenin

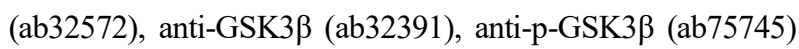
(Abcam, Cambridge, UK)를 제조사의 사용법에 따라 사용 하였다.

\section{RT-PCR}

세포를 Trizol (Ambion, CA, USA) 용액으로 처리하여 total RNA를 분리한 후 Accupower Roketscript cycle RT premix (Bioneer Corp. Korea)을 이용하여 cDNA를 합성하 였다. $\mathrm{PCR}$ 조건은 $94^{\circ} \mathrm{C} 3$ 분간 predenature하고 $94^{\circ} \mathrm{C} 30$ 초, $72^{\circ} \mathrm{C} 1$ 분을 30 cycle 거친 후, $72^{\circ} \mathrm{C} 10$ 분으로 하였다. PCR 의 결과는 $2.5 \%$ agarose gel에서 확인하였다. 사용한 primer
는 Table 1 과 같다.

\section{ABTS 라디칼 소거능 측정}

$\mathrm{ABTS}$ 라디칼 소거능 측정은 ABTS (2,-azino-bis-3ethylbenzothiazoline-6-sulphonic acid) $7 \mathrm{mM}$ 과 Potassium persulfate $2.4 \mathrm{mM}$ 을 $1: 1$ 혼합하고 24 시간 동안 암실에 반 응시킨 후 $650 \mathrm{~nm}$ 에서 흡광도가 0.7 이 되도록 멸균수로 희석한 $\mathrm{ABTS}$ 용액 $80 \mu \mathrm{L}$ 와 시료 추출물 $20 \mu \mathrm{L}$ 를 첨가하 여 실온에서 10 분, 20 분, 30 분간 반응시킨 후 microplate reader로 $650 \mathrm{~nm}$ 에서 흡광도를 측정하였다. 라디칼 소거능 (\%)은 [1-(시료첨가구 흡광도/무처리구 흡광도)] $\times 100$ 으 로 계산하였다.

\section{통계처리}

실험은 3회 반복하였고, 결과는 평균(mean) \pm 표준편차 (SD)로 나타내었다. Student's $t$-test 및 일원배치 분산분석 (one-way analysis of variance)을 이용하여 통계적으로 분석 하였으며, $P$ 값이 0.05 이하이면 유의성이 있다고 판단하 였다.

\section{결 과}

\section{단감의 꽃봉오리 및 과실 추출물의 세포독성 평가}

세포에 독성을 주지 않는 농도에서 단감의 꽃봉오리 및 과실 추출물을 세포에 처리하기 위하여 MTT assay를 실시하였다. RAW264.7 macrophage cell을 96 well plate에 $1 \times 10^{4}$ cells/well로 seeding하고 24 시간 배양한 후, $0.5 \mu \mathrm{g}$ $\mathrm{mL}$ 의 LPS (lipopolysaccharide)와 DMSO에 녹인 단감의 꽃 봉오리 및 과실 추출물을 농도 별로 혼합하여 투여하고 5 시간 배양 후 세포 생존율을 측정하였다. 그 결과 꽃봉 오리 추출물은 $60 \mu \mathrm{g} / \mathrm{mL}$, 과실 추출물은 $100 \mu \mathrm{g} / \mathrm{mL}$ 에서 $80 \%$ 이상의 생존율을 나타내었고 이후 실험에서 이 농도 를 활성 시험에 사용하였다(Fig. 1).

\section{꽃봉오리 및 과실 추출물에 의한 NF- $\mathrm{KB}$ 활성 억제 효과}

NF- $\kappa \mathrm{B}$ 는 세균의 LPS, TNF- $\alpha$ (tumor necrosis factor $\alpha$ ), 바 이러스 감염 등 염증을 일으키는 물질이 세포를 자극하 였을 때 활성화되어 염증 유발 물질의 발현을 증가시키 는 대표적인 전사인자이다(Karin and Ben-Neriah, 2000). 단 감의 꽃봉오리 및 과실 추출물이 염증을 일으키는 NF-kB 를 억제하는 효과가 있는지 검토하기 위하여 Luciferase reporter gene을 이용한 NF-kB 활성 분석을 실시하였다. 실 험 결과, Fig. 2A에 나타난 바와 같이 RAW264.7 세포에 


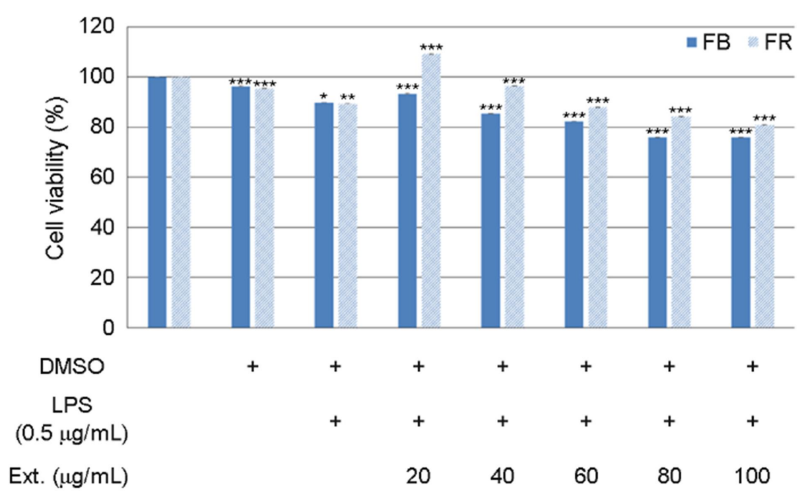

Fig. 1. Effect of the extract of Flower bud or fruit on the viability of RAW264.7 cells stimulated by LPS. RAW264.7 cells were incubated with LPS $(0.5 \mu \mathrm{g} / \mathrm{mL})$ and increasing concentrations of the extract of flower bud (FB) or fruit (FR) dissolved in DMSO for $5 \mathrm{~h}$, and the cell viability was measured by MTT assay (mean \pm SD, $\mathrm{n}=3, * P<0.05, * * P<.01, * * * P<0.001)$

LPS $(0.5 \mu \mathrm{g} / \mathrm{mL})$ 를 처리하였을 때 NF-kB는 현저하게 증가 하였으며, LPS에 꽃봉오리 $(60 \mu \mathrm{g} / \mathrm{mL})$ 또는 과실 $(100 \mu \mathrm{g} /$ $\mathrm{mL}$ ) 추출물을 함께 처리한 경우는 NF-kB 활성이 현저하 게 감소하였고 감소 효과는 꽃봉오리 추출물이 과실 추 출물보다 조금 높게 나타났다. 이 결과로부터 단감의 꽃 봉오리와 과실 추출물은 NF-kB 활성을 억제함을 알 수 있었다.

$\mathrm{NF}-\mathrm{kB}$ 는 비활성화 상태에서는 Inhibitor인 IKB $\alpha$ 에 결합 되어 세포질에 머물러있으며 NF-KB를 활성화시키는 요 인이 작용하였을 때는 IKB $\alpha$ 가 인산화 및 ubiquitinization 되어 파괴됨으로서 자유롭게 핵 내로 이동하여 전사인자 로 작용한다(Karin and Ben-Neriah, 2000). 그러므로 세포 내 $\mathrm{IkB} \alpha$ 는 NF-kB가 활성화되면 인산화된 $\mathrm{IkB} \alpha(\mathrm{p}-\mathrm{I} \mathrm{I} \mathrm{B} \alpha)$ 는 증가하고 인산화되지 않은 $\mathrm{I} \kappa \mathrm{B} \alpha$ 는 감소하며 비활성화 상 태에서는 $\mathrm{p}-\mathrm{I} \mathrm{I} \mathrm{B} \alpha$ 는 감소하고 $\mathrm{I} \kappa \mathrm{B} \alpha$ 는 증가한다. 꽃봉오리 및 과실 추출물의 NF-KB 활성 억제 효과를 확인하기 위 하여 RAW264.7 세포에 LPS를 처리한 경우와 LPS와 꽃 봉오리 또는 과실 추출물을 함께 처리한 경우에서 세포 내 $\mathrm{p}-\mathrm{I} \kappa \mathrm{B} \alpha$ 와 $\mathrm{I} \kappa \mathrm{B} \alpha$ 의 양을 Western blotting으로 측정하였다. 그 결과 Fig. $2 \mathrm{~B}$ 에 나타난 바와 같이 LPS 처리에 의해 $\mathrm{p}-$ $\mathrm{I} \kappa \mathrm{B} \alpha$ 는 증가하고 $\mathrm{I} \kappa \mathrm{B} \alpha$ 는 감소하여 NF- $\mathrm{KB}$ 가 활성화되었 음을 나타내었고, 꽃봉오리 및 과실 추출물에 의해 $\mathrm{p}-\mathrm{I} \mathrm{KBo}$ 의 감소와 함께 $\mathrm{I \kappa B} \alpha$ 가 증가하여 NF-kB 의 활성이 억제되 었음을 나타내었다. 이 결과로부터 단감의 꽃봉오리와 과실 추출물은 $\mathrm{I} \kappa \mathrm{B} \alpha$ 의 분해를 방지하여 NF- $\mathrm{KB}$ 의 활성화 를 억제함을 알 수 있었다. 또한 NF-kB의 활성화에 의해
A

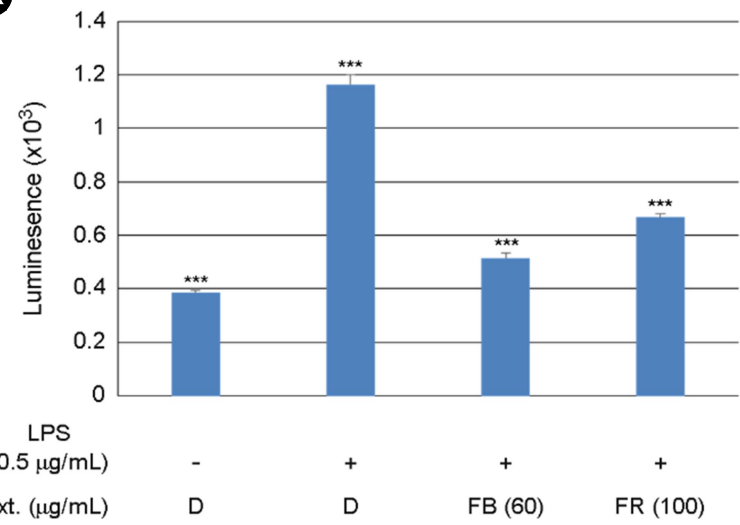

B

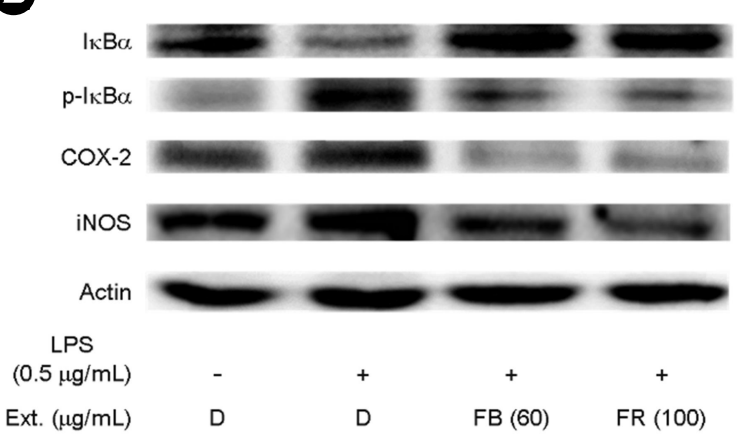

Fig. 2. Effect of the extract of Flower bud or fruit on the NF-KB activation. RAW264.7 cells were transfected with pNL3.2 NF-KB RE plasmid and treated with LPS and the extract of flower bud (FB) or fruit (FR) dissolved in DMSO (D) for $24 \mathrm{~h}$. The NF-KB activity was measured by luciferase activity (A) (mean $\pm \mathrm{SD}, \mathrm{n}=3$, *** $P<$ 0.001 ), and the proteins were detected by Western blotting (B)

발현이 증가하는 유전자 중에서 염증을 일으키는 대표적 인 유전자들인 COX-2와 $\mathrm{iNOS}$ 의 발현이 꽃봉오리 및 과 실 추출물에 의해 현저하게 감소하였다(Fig. 2B). 아울러, NF-kB에 의해 발현이 증가하여 염증을 유발하는 proinflammatory cytokine의 발현을 RT-PCR로 검토한 결과 Fig. 3 에 나타난 바와 같이 LPS에 의해 IL-1 $\beta, \mathrm{IL}-6, \mathrm{TNF}-\alpha$ 모 두 발현이 증가하였으나, IL- $\beta$ 와 IL-6는 꽃봉오리 및 과실 추출물에 의해 발현이 현저하게 감소하였고 TNF- $\alpha$ 는 과 실 추출물에 의해 발현이 현저하게 감소하였다. 이러한 결과는 꽃봉오리 및 과실 추출물에 의한 NF-kB의 활성 저해가 실제로 염증을 일으키는 NF-kB의 target gene들의 발현을 감소시켜 항염증 작용을 나타냄을 의미한다. 


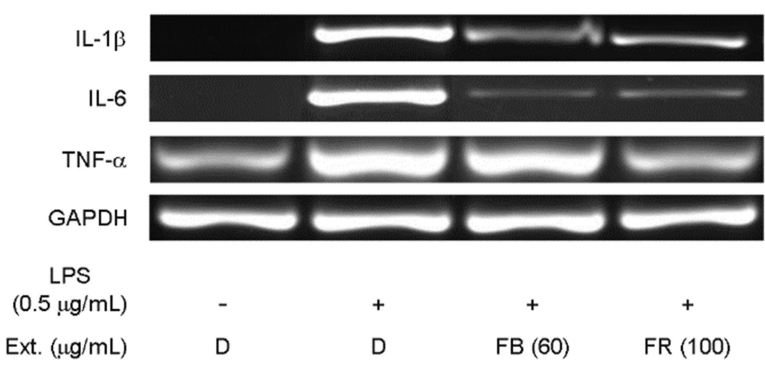

Fig. 3. Effect of the extract of flower bud or fruit on the expression of pro-inflammatory cytokines. RAW264.7 cells were treated with LPS and the extract of flower bud (FB) or fruit (FR) dissolved in DMSO (D) and after $5 \mathrm{~h}$, the mRNA level of each protein was evaluated by RT-PCR.

\section{꽃봉오리 및 과실 추출물에 의한 $\mathrm{wnt} / \beta-$ catenin 경로 의 억제 효과}

Wnt/ $\beta$-catenin 신호전달 경로는 세포 증식과 조직의 형 성 및 발달과 같은 다양한 생물학적 활성에 관여하며 염 증성 질환을 비롯한 다양한 질병에도 연관되어 있다. 정 상적인 wnt/ $\beta$-catenin 신호 경로의 활성화는 조직의 재생 과 유지에 필요하지만 wnt/ $\beta$-catenin의 비정상적인 과다 활성화는 염증 발생의 원인이 된다(Jang et al., 2014). 또한, wnt/ $\beta$-catenin은 염증을 유발하는 TNF- $\alpha$, IFN- $\gamma$, IL-1 $\beta$, IL-6 등에 의해 활성화되어 염증을 유발하는 것으로 알려져있 다(Moparthi and Koch, 2019). 그러므로 과다 활성화된 wnt/ $\beta$-catenin에 대한 꽃봉오리 및 과실 추출물의 억제 효과를 검토하였다. RAW264.7 세포에 LPS와 꽃봉오리 및 과실 추출물을 5 시간 동안 처리한 후 $w n t / \beta$-catenin을 활성화시 키는 인산화된 GSK3 $\beta$ (p-GSK3 $\beta$ )의 변화를 확인한 결과 Fig. $4 \mathrm{~A}$ 에 나타난 바와 같이 꽃봉오리와 과실 추출물에 의해 p-GSK3 3 가 현저하게 감소함을 알 수 있었으며 이에 따라 $\beta$-catenin도 현저하게 감소하였다. 또한 꽃봉오리 및 과실 추출물에 의한 wnt $\beta$-catenin의 target gene으로 알려져 있는 Cyclin D1 및 Wnt family gene들의 발현 양 변화를 검 토한 결과 LPS에 의해 증가한 Cyclin D1 및 Wnt 3a, Wnt $5 \mathrm{a}$ 의 발현이 꽃봉오리와 과실 추출물에 의해 현저하게 억제됨을 알 수 있었다(Fig. 4B). 이러한 결과로부터 꽃봉 오리 및 과실 추출물은 wnt/ $\beta$-catenin의 신호 경로를 억제 함으로써 항염증 효과를 나타냄을 알 수 있었다.

\section{꽃봉오리 및 과실 추출물의 항산화 효과 및 apoptosis 억제 효과}

산화적 스트레스(oxidative stress)는 다양한 염증성 질병
(A)

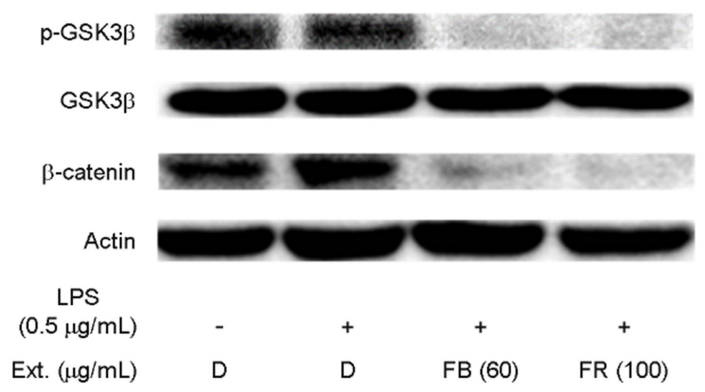

B

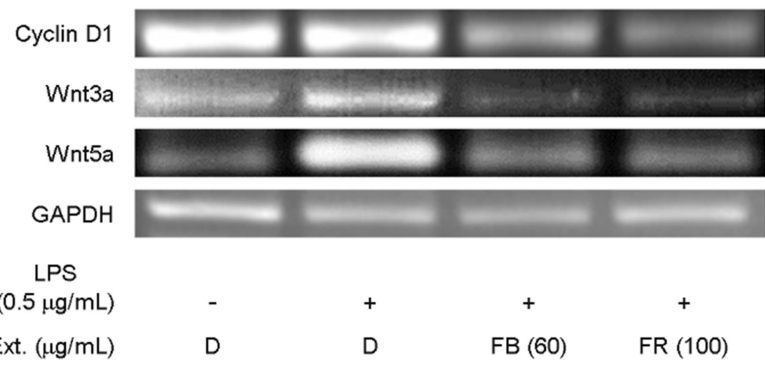

Fig. 4. Effect of the extract of flower bud or fruit on the activation of wnt/ $\beta$-catenin signaling pathway. RAW264.7 cells were treated with LPS and the extract of flower bud (FB) or fruit (FR) dissolved in DMSO (D) for $5 \mathrm{~h}$. The protein expressions were analyzed by Western-blotting (A), and the mRNA levels were evaluated by RT-PCR (B).

을 일으키거나 심화시키는 것으로 알려져있다(Naik and Dixit, 2011; Mittal et al., 2014). 단감의 감 잎, 박피, 과육 등 의 항산화 효능에 대해서는 다양한 추출법에 의한 단감 추출물을 이용한 연구결과가 보고되었으나(Lee et al., 2010; You et al., 2010) 꽃봉오리 및 어린 과실의 항산화 효능에 대해서는 보고된 바가 없으므로 이들의 항산화 효능을 ABTS free radical 소거 활성으로 검토하였다. 그 결과 Fig $5 \mathrm{~A}$ 에 나타난 바와 같이 추출물을 함유하지 않은 DMSO 대조군에 비해 꽃봉오리와 과실 추출물 모두 높은 free radical 소거능을 나타내었다. 이러한 항산화 효능은 꽃봉 오리 및 과실 추출물의 항염증 효능을 더욱 강화시킬 것 으로 보여진다. 한편, LPS는 염증을 유발할 뿐 아니라 세 포의 apoptosis를 유도하고 세포의 생존율을 떨어뜨리며 이로 인한 조직의 손상을 초래하는 것으로 알려져 있다 (Li et al., 2014; Lei et al., 2018). 그러므로 단감의 꽃봉오리 및 과실 추출물의 apoptosis 억제 효능을 검토하였다. Fig. $5 \mathrm{~B}$ 에 나타난 바와 같이 RAW264.7 세포에 LPS를 처리한 결과 apoptosis를 억제하는 Bc12는 현저히 감소하고 apoptosis를 일으키는 Bax는 현저히 증가하였다. 이로써 LPS 
A

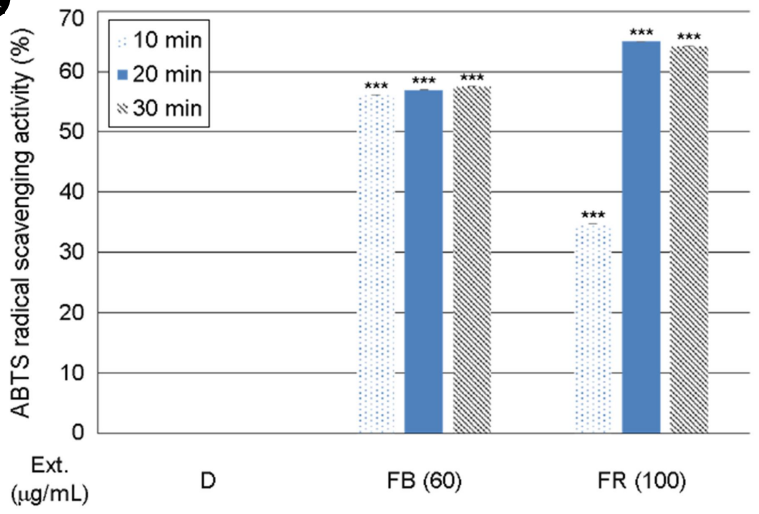

B

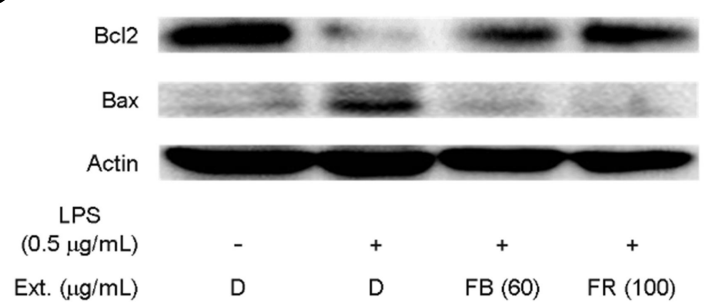

Fig. 5. Anti-oxidant and anti-apoptotic effects of the extracts of flower bud and fruit. (A) Anti-oxidant activity was assayed by ABTS radical scavenging activity with the extract of flower bud (FB) or fruit (FR) dissolved in DMSO (D) (mean $\pm \mathrm{SD}, \mathrm{n}=3$, $* * * P<$ 0.001). (B) Raw264.7 cells were treated with LPS and extract for $5 \mathrm{~h}$ as indicated and the expressions of anti-apoptotic $\mathrm{Bcl}_{2}$ and pro-apoptotic Bax were detected by Western-blotting.

가 apoptosis를 유도함을 알 수 있었고, 여기에 꽃봉오리 및 과실 추출물을 처리한 결과 $\mathrm{Bcl} 2$ 는 현저히 증가하고 $\mathrm{Bax}$ 는 현저히 감소함으로써 꽃봉오리와 과실 추출물 모 두 apoptosis를 억제함을 알 수 있었다. 이로부터 꽃봉오 리와 과실 추출물은 LPS에 의한 염증을 억제할 뿐 아니 라 apoptosis도 억제함으로써 조직의 손상을 방지하는 것 을 알 수 있었다.

\section{고 찰}

단감의 생리 활성에 관한 연구는 광범위하게 이루어 져 많은 연구보고가 이루어졌다. 단감의 과피와 과육은 항산화 작용(Uchida et al., 1987)과 항균, 항바이러스 작용 (Kawase et al., 2003)이 있는 것으로 보고되었고 감잎 추출 물은 항알러지 작용(Kotani et al., 2000) 및 항암 작용(Song et al., 2000)이 있는 것으로 보고되었다. 그러나 단감의 항 염증 작용에 관해서는 구체적인 보고가 없으며 특히 단감
의 꽃봉오리와 어린 과실 추출물에 의한 항염증 작용에 관한 보고는 아직 이루어지지 않고 있다. 본 연구에서는 단감의 항염증 작용의 구체적인 기전을 밝히고, 특히 단 감의 꽃봉오리 추출물과 어린 과실 추출물에 의한 항염 증 작용을 비교 검토함으로써 단감의 항염증 작용을 명 확히 하고자 하였다. 먼저 생체 내 신호전달 회로 중에서 염증 유발의 핵심적인 회로로 알려져 있는 NF-kB의 활성 화 회로에 대한 단감의 꽃봉오리 및 과실 추출물의 영향 을 검토하였다. 염증을 유발하는 NF-kB의 활성화 회로는 canonical pathway의 경우 TNF- $\alpha$, IL-1 등의 cytokine이나 LPS에 의해 활성화 된다(Karin and Ben-Neriah, 2000). 본 연구에서는 LPS를 이용한 canonical pathway의 활성화 경 로를 이용하였으며 LPS에 의해 활성화된 IKK $\beta$ 가 NF-KB 의 inhibitor인 $\mathrm{I} \kappa \mathrm{B} \alpha$ 를 인산화시켜 파괴함으로써 NF- $\mathrm{kB}$ 가 활성화된다. RAW264.7 세포에 LPS를 처리하여 NF-kB를 유도할 때 단감 추출물을 첨가하여 그 효과를 검토한 결 과 꽃봉오리와 과실 추출물 모두 LPS에 의한 NF- $\mathrm{KB}$ 의 활성화를 현저하게 저해하였다. 이때 LPS에 의해 감소된 $\mathrm{I} \mathrm{KB} \alpha$ 가 단감 추출물에 의해 증가함으로써 꽃봉오리와 과 실 추출물은 NF-kB의 canonical pathway를 저해함을 확인 할 수 있었으며, NF-кB에 의해 발현이 증가되어 염증을 일으키는 핵심적인 효소인 COX-2 및 iNOS의 발현과 NF$\kappa \mathrm{B}$ 에 의해 발현이 유도되어 염증을 유발하는 cytokine인 $\mathrm{IL}-1 \beta, \mathrm{IL}-6, \mathrm{TNF}-\alpha$ 의 발현이 꽃봉오리와 과실 추출물에 의해 현저하게 감소한 것을 확인함으로써 이들 추출물이 $\mathrm{NF}-\mathrm{kB}$ 를 억제하여 항염증 효과를 나타냄을 명확하게 알 수 있었다.

한편 최근 연구에서 wnt/ $\beta$-catenin은 다양한 염증 유발 경로에 연관되어 있음이 밝혀지고 있으며 특히 염증 유 발의 핵심 경로인 NF-kB와 상호 조절하는 것으로 알려졌 다(Ma and Hottiger, 2016). 또한 wnt/ $\beta$-catenin은 LPS에 의 해 활성화되어 LPS에 의한 조직의 손상을 가중시키는 것 으로 보고되었으며(Villar et al., 2011), 골관절염 환자의 연 골조직에서 과다 활성화됨이 보고되었고, wnt $\beta$-catenin의 저해는 이러한 조직의 손상과 염증을 완화시키는 것으로 알려졌다(Xi et al., 2020). 본 연구에서 단감의 꽃봉오리 및 과실 추출물은 wnt/ $\beta$-catenin을 강하게 억제하였고 wnt/ $\beta$-catenin의 target 유전자의 발현도 현저하게 저해함이 확 인되었으며 이는 이들 추출물이 NF-kB의 억제와 더불어 wnt/ $\beta$-catenin도 억제함으로써 강한 항염증 효과를 나타냄 을 보여주는 것으로 해석된다. 또한, 본 연구에서 단감의 꽃봉오리 및 과실 추출물은 강한 항산화 효과를 보였다. 
단감의 항산화 효능은 여러 선행연구에서 보고되었으나 (Lee et al., 2010; You et al., 2010) 꽃봉오리가 과실에 못지 않은 항산화 효능을 가진다는 사실은 본 연구에서 처음으 로 확인되었다. 활성 산소에 의한 산화적 스트레스는 다 양한 염증과 조직 손상의 원인으로 알려져 있으며(Mittal et al., 2014), 본 연구에서 강한 항산화 작용을 보인 꽃봉 오리와 과실 추출물은 항산화 작용을 통하여 효과적인 항염증 및 조직 손상 억제 작용을 할 것으로 보인다. 또 한 LPS는 염증과 산화적 스트레스를 유발할 뿐 아니라 apoptosis를 일으킴으로써 조직의 손상을 초래하는 것으 로 알려져 있는데(Li et al., 2014) 본 연구에서 단감의 꽃 봉오리와 과실 추출물은 anti-apoptotic $\mathrm{Bcl} 2$ 를 증가시키고 pro-apoptotic Bax를 감소시킴으로써 apoptosis를 억제하는 효능을 가지는 것으로 밝혀졌다. 이는 이들 추출물이 염 증 억제 작용과 더불어 염증과 연관된 apoptosis를 억제함 으로써 염증을 개선하고 조직을 보호하는 작용을 가짐을 보여준다고 할 수 있다. 이상의 결과로부터 단감의 꽃봉 오리와 과실의 항염증 작용의 기전이 많은 부분 밝혀졌 으며, 특히 꽃봉오리에도 과실에 못지 않는 강한 항염증 작용이 있음을 알 수 있었고 이는 적뢰시 솎아내어 폐기 하는 꽃봉오리를 이용하여 다양한 상품을 개발할 수 있는 가능성을 보여준다는 점에서 의미 있는 연구결과라고 할 수 있다.

\section{ACKNOWLEDGEMENT}

This research is supported by Changwon National University in 2019-2020.

\section{CONFLICT OF INTEREST}

No potential conflict of interest relevant to this article was reported.

\section{REFERENCES}

Achiwa Y, Hibasmi H, Katsuzaki H, Iami K, Komiya T. Inhibitory effects of persimmon (Diospyros kaki) extract and related polyphenol compounds on growth of human lymphoid leukemicells Biosci Biothchnol Biochem. 1997. 61: 1099-1101.

Ben-Neriah Y, Karin M. Inflammation meets cancer, with NFkappaB as the matchmaker. Nat Immunol. 2011. 12: 715-723. Choi JH, Lee EY, Kim GJ, Park IH, Kim JS, Choi GB, Jung SG, Ham YS. Physicochemical properties and physiological activities of Ulsan sweet persimmon peel $\cdot$ flesh according to cultivars. J Korean Soc Appl Biol Chem. 2006. 49: 309-314.

Clevers H, Nusse R. Wnt/beta-catenin signaling and disease. Cell. 2012. 149: 1192-1205.

George AP, Redpath S. Health and medicinal benefits of persimmon fruit: a review. Adv Hort Sci. 2008. 22: 244-249.

Hanahan D, Weinberg RA. Hallmarks of cancer: the next generation. Cell. 2011. 144: 646-674.

Jang J, Ha JH, Chung SI, Yoon Y. Beta-catenin regulates NFkappaB activity and inflammatory cytokine expression in bronchial epithelial cells treated with lipopolysaccharide. Int J Mol Med. 2014. 34: 632-638.

Karin M, Ben-Neriah Y. Phosphorylation meets ubiquitination: the control of NF- $\kappa$ B activity. Annu Rev Immunol. 2000. 18 621-663.

Kawase M, Motohashi N, Satoh K, Sakagami H, Nakashima H, Tani S, Shirataki Y, Kurihara T, Spengler G, Wolfard K, Molnar J. Biological activity of persimmon (Diospyros kaki) peel extracts. Phytotheraphy Res. 2003. 17: 495-500.

Kotani M, Matsumoto M, Fujita A, Higa S, Wang W, Suemura M, Kishimoto T, Tanaka T. Persimmon leaf extract and astragalin inhibit development of dermatitis and $\mathrm{IgE}$ elevation in $\mathrm{NC} /$ Nga mice. J Allergy Clin Immunol. 2000. 106: 159-166.

Kuprash DV, Nedospasov SA. Molecular and cellular mechanisms of inflammation. Biochemistry (Moscow). 2016. 81: 1237 -1239 .

Lee JS, Lee MK, Ha TY, Bok SH, Park HM, Jeong KS, Woo MN Do GM, Yeo JY, Choi MS. Supplementation of whole persimmon leaf improves lipid profiles and suppresses body weight gain in rats fed high-fat diet. Food Chem Toxicol 2006. 44: 1875-1883.

Lee SJ, Ryu JH, Kim RJ, Lee HJ, Sung NJ. Effect of removed peel from sweet persimmon on nutritional ingredients and antioxidant activities. J Korean Soc Food Sci Nutr. 2010. 39 1495-1502.

Lei L, Wan G, Han B, Zhang Z. Echinacoside alleviated LPSinduced cell apoptosis and inflammation in rat intestine epithelial cells by inhibiting the mTOR/STAT3 pathway. Biomedicine \& Pharmacotherapy. 2018. 104: 622-628.

Li C, Xu MM, Wang K, Adler AJ, Vella AT, Zhou B. Macrophage polarization and Meta-inflammation. Transl Res. 2018. 191: 29-44.

Li X, Gou C, Yang H, Qiu J, Gu T, Wen T. Echinacoside ameliorates D-galactosamine plus lipopolysaccharide-induced acute 
liver injury in mice via inhibition of apoptosis and inflammation. Scand J Gastroenterol. 2014. 49: 993-1000.

Ma B, Hottiger MO. Crosstalk between wnt $/ \beta$-catenin and NF- $\kappa B$ signaling pathway during inflammation. Front Immunol. 2016. 7: 378.

Mittal M, Siddiqui MR, Tran K, Reddy SP, Malik AB. Reactive oxygen species in inflammation and tissue injury. Antioxid Redox Signal. 2014. 20: 1126-1167.

Moparthi L, Koch S. Wnt signaling in intestinal inflammation. Differentiation. 2019. 108: 24-32.

Naik E, Dixit VM. Mitochondrial reactive oxygen species drive proinflammatory cytokine production. J Exp Med. 2011. 208: 417-420.

Sartor RB. Pathogenesis and immune mechanisms of chronic inflammatory bowel disease. Am J Gastroenterol. 1997. 92: $5 \mathrm{~S}-11 \mathrm{~S}$

Song HS, Lee HK, Kang MH. Antimutagenic effects of persimmon leaf tea extract (PLTE) in mice using micro-nucleus induction (MN) test. J Korean Soc Food Sci Nutr. 2000. 29: 881-887.

Symmons DP. Epidemiology research in rheumatology - progress and pitfalls. Nat Rev Rheumatol. 2015. 11: 631-638.

Tak PP, Firestein GS. NF-kappaB: a key role in inflammatory disease. J Clin Invest. 2001. 107: 7-11.

Uchida S, Nishioka I, Niwa M, Ozaki M. Condensed tannins scavenge active oxygen free radical. Med Sci Res. 1987. 15: 831-835

Villar J, Cabrera NE, Casula M, Valladares F, Flores C, LopezAguilar J, Blanch L, Zhang H, Kacmarek RM, Slutsky AS. $\mathrm{Wnt} / \beta$-catenin signaling is modulated by mechanical ventilation in an experimental model of acute lung injury. Intensive Care Med. 2011. 37: 1201-1209.

Xi Y, Huang X, Tan G, Chu X, Zhang R, Ma X, Ni B, You H. Protective effects of Erdosteine on interleukin-1 $\beta$-stimulated inflammation via inhibiting the activation of MAPK, NF- $\mathrm{BB}$, and $\mathrm{Wnt} / \beta$-catenin signaling pathways in rat osteoarthritis. European J Pharmacol. 2020. 873: 172925.

You DH, Jang IC, Seo GU, Kim SJ, Yang EK, Ahn GH, Matsushita Y, Fukushima K, Lee SC. Antioxidant activity of branches of fuyu and nishimurawase persimmon trees. J Appl Biol Chem. 2010. 53: 82-86.

https://doi.org/10.15616/BSL.2020.26.2.85

Cite this article as: Park YO, Lee JA, Park SM, Ha MH, Joo WH, Kim DW. Anti-inflammatory Effect of Flower Bud and Fruit of Sweet Persimmon, Diospyros kaki T. Biomedical Science Letters. 2020. 26: 85-92. 